\title{
"Metabolic Ride" - One Concept Evaluation Tool For Metabolic Biochemistry Teaching For Graduate Students In Biological Sciences And Related Areas.
}

\author{
Gaeta, H. H. ${ }^{1}$; Ortolan, B. D. ${ }^{1}$, Cruz, C. R. C. ${ }^{1}$, Belchor, M. N. ${ }^{1,2}$, Rodrigues, C. F. B. ${ }^{1,3}$; \\ Toyama, D. O. ${ }^{1,4}$, Toyama, M. H. ${ }^{1}$
}

1 UNESP Instituto de Biociências, Campus do Litoral Paulista, Praça Infante Dom Henrique s $/ \mathrm{n}^{\circ}$, Bairro: Parque Bitaru - CEP 11330-900 - São Vicente; ${ }^{2}$ Programa de Pós-Graduação em Alimentos, Nutrição e Saúde, UNIFESP Campus Baixada Santista, Instituto de Saúde e Sociedade, Avenida Ana Costa, 95 - Gonzaga Santos, SP - CEP 11060-001; 'Programa de Pós-Graduação Interunidades em Biotecnologia Universidade de São Paulo (ICB, IB, FMVZ, EP) - Instituto Butantan Instituto de pesquisas tecnológicas, Avenida Prof. Lineu Prestes, 2415 - Edifício ICB - III Cidade Universitária CEP 05508-900, São Paulo, SP; ${ }^{4}$ Pró-Reitoria de PósGraduação, Universidade Brasil, Campus São Paulo - Rua Carolina Fonseca, 584 Itaquera • São Paulo/SP.

INTRODUCTION. Biochemistry subject in general has a high degree of difficulty and complexity. Therefore, application of playful and creative games as teaching methodology has spread in various disciplines of life sciences. "METABOLIC RIDE" board game is a conceptual and perceptual evaluation tool for metabolic biochemistry teaching, aiming to review concepts transmitted in classroom, promoting a competitive challenge to students without denying tools that are at their disposal, stimulating their skills. OBJECTIVES. Correlate metabolic routes importance and their interconnections to establish that metabolic pathways are interconnected, such as a railway map. MATERIAL AND METHODS. This game was developed based on a board game Ticket to Ride. Players purchase enzyme cards, which must be used to claim metabolic routes. The goal is to complete the route previously drawn to earn points and the player who builds the longest continuous route will also earn bonus points. In each turn, players can: buy more card, claim a route or pick up additional destination tickets. The game should be played in groups of 5 to 6 students in 6 to 8 groups. Previously there will be theoretical classes. The activity was designed to last 4 hours. Use of didatic books and internet by players are encouraged. RESULTS. This game proved to be an excellent tool for student's complementary evaluation, which stimulated teamwork and competitiveness within classroom, which allowed to analyze student's perception regarding metabolic subjects. On the other hand, for teacher and students participating in compulsory traineeship program this game demonstrated to students new ways to approach complex subjects in biochemistry using creativity. CONCLUSION: Overall, students had a good impression of "Metabolic Ride" game since it helped to secure and administer metabolism subject in a competitive and team work way.

Key words: didactic game, metabolic map, review. 